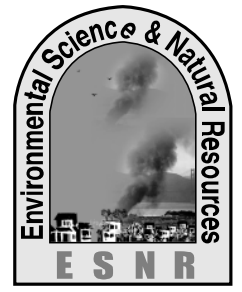

J. Environ. Sci. \& Natural Resources, 5(2): 301 - 306, 2012

ISSN 1999-7361

\title{
Effects of Variety and Growing Condition on Yield and Quality of Carrot Seed
}

\author{
M. A. Malek ${ }^{1}$, D. Mohammed ${ }^{1}$, M. Sikdar ${ }^{2}$ and M. S. Rahman $^{3}$ \\ Department of Horticulture, Patuakhali Science and Technology University, Patuakhali \\ ${ }^{1}$ Public Relations \& Publications Section, BAU, Mymensingh \\ ${ }^{2}$ Metal Agro limited, Salna, Gazipur \\ ${ }^{3}$ RARS, BARI, Akbarpur, Moulvibazar
}

\begin{abstract}
Different varieties of carrot and growing conditions of stecklings showed highly significant influence all most all the parameters studied. The highest seed yield (1321.53 kg/ha) was recorded from Brasilia Agroflora and the quality of seed (germination $83.20 \%$ and seed vigour index 12.21) was produced from the same variety, while the lowest seed yield (1193.70 kg/ha) and germination $(79.42 \%)$ were obtained from New Kuroda. The net covered stecklings were recorded the highest seed yield (1495.33 $\mathrm{kg} / \mathrm{ha}$ ) and the quality of seed (germination $86.93 \%$ and seed vigour index 13.17) was produced from the same condition, while the lowest seed yield $(1047.14 \mathrm{~kg} / \mathrm{ha})$ and germination $(75.77 \%)$ were obtained from polythene covered stecklings. In case of combined effect, the highest seed yield $(1576.07 \mathrm{~kg} / \mathrm{ha}$ ) was recorded from Brasilia Agroflora with net covered stecklings and that of the lowest $(1000.10 \mathrm{~kg} / \mathrm{ha})$ from New Kuroda with polythene covered stecklings.
\end{abstract}

Key words: Growing condition, Quality seed, Stecklings, Yield

\section{Introduction}

Carrot is an important root vegetable crop from nutritional point of view. It plays a vital role to protect the blindness of children providing vitamin A. In Bangladesh, there is no recommended variety of carrot for seed production. Many countries have developed good quality high yielding varieties through introduction. For the development of suitable varieties, it is essential to evaluate the characters of the available germplasm properly and conserve the collected materials for future use. Almost entire production of carrot in Bangladesh depends on imported seeds. These are relatively expensive which are not always available in time for sowing. So, cultivation of good quality carrot falls in an uncertainty. This situation also restricts its production. To save the foreign currency and to increase carrot production, timely supply of quality seed in desired quantity should be ensured. This is possible through the improvement of seed production. Hence, the genetic information of different varieties on yield, yield contributing characters and quality of carrot seed producing species are to be assessed for its improvement.

Again, growing conditions of stecklings are considered as another important factor for proper flowering, fruiting and maximizing viable seed production. Carrot is generally uprooted before on-set of their reproductive phase and then replanted after cutting a part of their fleshy roots to avoid vertical degeneration and to ensure quality seed production. Growing condition of uprooted plants (stecklings) has influence on the yield and quality of seed. It is also influences the growth and thus, on seed yield and quality. This information needs thorough study to standardize the field condition for quality seed production of carrot. So, it is essential to know the actual growing condition for maximizing the quality seed yield. Therefore, the present study was designed to establish the suitable variety and proper growing condition of stecklings for maximizing the yield and quality of carrot seed.

\section{Materials and Methods}

The experiment was conducted at Horticulture Farm, Bangladesh Agricultural University, Mymensingh during September, 2011 to June, 2012. Three varieties of carrot viz. Brasilia Agroflora, Prima Agroflora and New Kuroda, and three different growing conditions viz. open field, polythene covered and net covered stecklings were used in this study. The unit plot size was $1 \mathrm{~m} \times 1 \mathrm{~m}$. Seeds were sown uniformly in rows in 15 September'11 and 75 days old stecklings were transplanted in 2 December'11. The selected land was medium high and the texture of soil was clay loam. The two-factor experiment was laid out in RCBD with three replications. The experimental plot was prepared by good tilth and fertilized with recommended doses of manures and fertilizers. The seeds of carrot varieties were collected from USDAAlliums' project, Department of Horticulture, BAU, Mymensingh. All intercultural operations were done as and when needed. The matured umbels were harvested in several phases, when the umbel turned into grayish in colour. Seeds were then collected by hand rubbing, cleaned and dried until they reached in safe moisture (7-9\%) level. 
After 30 days of storage, the seeds of each treatment were placed for germination test and measure vigour index in petridishes methods, taking 100 seeds for each treatment with blotting papers in the laboratory. The seed vigour was measured through its speed of germination. The germinated seeds were counted every day until germination was completed. An index of the speed of germination was then calculated by adding the quotients of the daily counts divided by the number of days of germination using the formula described by Agrawal (1996) as below: Seed vigour index $=($ No. of seed germinated at first count/No. of days required to first count $)+\ldots \ldots . .+$ (No. of seed germinated at last count/No. of days to last count). Thus, the seeds with higher index has faster germination rate and would be considered to be higher in vigour. Data were recorded on vegetative growth and flowering behavior, yield components, yield and quality contributing characteristics of carrot from five randomly selected plants of each plot and were analyzed statistically by Mstatc computer programme. The difference between the treatment means was adjudging by least significant difference (LSD) test.

\section{Effect of variety}

\section{Results and Discussion}

It is evident from the Table 1 that variety significantly influenced all most all of the parameters under study. The tallest plant height $(145.35 \mathrm{~cm})$ was measured in Brasilia Agroflora and the most dwarf $(127.75 \mathrm{~cm})$ from New Kuroda. This might be due to genetical phenomena of these varieties. The results are in agreement with Sharma et al. (1990). Minimum days required for 50\% flowering (57.86 days) was noted in variety Brasilia Agroflora whereas, New Kuroda took 60.72 days. Maximum time required (13.81 days) from flower to fruit set was found in New Kuroda and minimum time (12.68 days) in Brasilia Agroflora. The highest number of primary umbels/plant (10.02) was recorded in Brasilia Agroflora, while the lowest (8.76) was found in New Kuroda. The highest seed yield in primary umbel $(4.79 \mathrm{~g})$ was recorded in Brasilia Agroflora but New Kuroda demonstrated the lowest $(4.28 \mathrm{~g})$. A similar report was revealed by Cardoso (2000), who stated that seeds in the primary umbels were of better seed yield and quality than the seeds of secondary umbel.

Brasilia Agroflora gave the highest seed yield/ha $(1321.53 \mathrm{~kg}$ ) followed by Prima Agroflora (1263.51 $\mathrm{kg})$ and it was the lowest $(1193.70 \mathrm{~kg})$ in New Kuroda (Fig. 1). This might be due to the fact that the variety Brasilia Agroflora had a good genetic potential which enhanced more cell division and cell elongation resulting best performance. This result agrees with Mohanty (1998). Mohanty and Prusti (2001) reported that seed yields vary with the cultivars. This might be due to higher umbel size, number of seeds/ umbel and 1000-seed weight. Maximum 1000 -seed weight $(1.67 \mathrm{~g})$ was recorded in Prima Agroflora, while New Kuroda gave minimum (1.09g). Malik et al. (1993) found 1000-seed weight of carrot $0.96 \mathrm{~g}$. This result is in agreement with this finding. The highest quality of seed (germination $83.20 \%$ and vigour index 12.21) was exhibited in Brasilia Agroflora followed by Prima Agroflora $(81.10 \% \& 11.89)$. The lowest quality of seed (germination $79.42 \%$ and vigour index 11.46) was observed in New Kuroda variety. This might be due to higher thousand seed weight which enhanced the speed of germination. This result is in agreement with the findings of Shantha et al. (1998). They found 80.2 $\%$ seed germination in carrot seed from primary umbel.

\section{Effect of growing condition}

Significant variation was observed of all the parameters under study (Table 1). The tallest plant height $(163.19 \mathrm{~cm})$ was measured in open field condition stecklings, while polythene covered stecklings showed the most dwarf $(109.99 \mathrm{~cm})$. The results are agreement with Sharma et al. (1990). 
Table 1. Main effect of variety and growing condition of stecklings on growth, yield contributing characters, yield and quality of carrot seed

\begin{tabular}{|c|c|c|c|c|c|c|c|c|c|c|c|c|}
\hline Treatments & $\begin{array}{c}\text { Plant } \\
\text { height } \\
\text { (cm) }\end{array}$ & $\begin{array}{c}\text { Days to } \\
50 \% \\
\text { flowering }\end{array}$ & $\begin{array}{c}\text { Days } \\
\text { to } \\
\mathbf{5 0 \%} \\
\text { fruit } \\
\text { set } \\
\end{array}$ & $\begin{array}{l}\text { Days } \\
\text { required } \\
\text { for fruit } \\
\text { set }\end{array}$ & $\begin{array}{c}\text { Primary } \\
\text { umbels/ } \\
\text { plant }\end{array}$ & $\begin{array}{c}\text { Secondary } \\
\text { umbel/ } \\
\text { plant }\end{array}$ & $\begin{array}{l}\text { Yield of } \\
\text { primary } \\
\text { umbel } \\
\text { (g) }\end{array}$ & $\begin{array}{c}\text { Yield of } \\
\text { secondary } \\
\text { umbel }(\mathrm{g})\end{array}$ & $\begin{array}{l}\text { Seed } \\
\text { yield/ } \\
\text { plant } \\
(\mathrm{g})\end{array}$ & $\begin{array}{l}1000- \\
\text { seed } \\
\text { weight } \\
(\mathrm{g})\end{array}$ & $\begin{array}{l}\text { Germination } \\
\% \text { of seed }\end{array}$ & $\begin{array}{c}\text { Seed } \\
\text { vigour } \\
\text { index }\end{array}$ \\
\hline \multicolumn{13}{|l|}{ Variety } \\
\hline $\begin{array}{l}\text { Brasilia } \\
\text { Agroflora }\end{array}$ & 145.35 & 57.86 & 70.52 & 12.68 & 10.02 & 15.69 & 4.79 & 3.45 & 8.32 & 1.24 & 83.20 & 12.21 \\
\hline $\begin{array}{l}\text { Prima } \\
\text { Agroflora }\end{array}$ & 135.48 & 59.14 & 71.80 & 13.17 & 9.63 & 14.49 & 4.56 & 3.30 & 7.92 & 1.67 & 81.10 & 11.89 \\
\hline $\begin{array}{l}\text { New } \\
\text { Kuroda }\end{array}$ & 127.75 & 60.72 & 73.85 & 13.81 & 8.76 & 13.58 & 4.28 & 3.18 & 7.49 & 1.09 & 79.42 & 11.46 \\
\hline LSD at $5 \%$ & 7.957 & 1.797 & 1.484 & - & 0.634 & 0.652 & 0.196 & 0.147 & 0.102 & 0.043 & 1.893 & 0.525 \\
\hline LSD at $1 \%$ & 10.76 & - & 2.006 & - & 0.857 & 0.881 & 0.265 & 0.199 & 0.137 & 0.059 & 2.560 & - \\
\hline $\begin{array}{l}\text { Level of } \\
\text { significance }\end{array}$ & $* *$ & $*$ & $* *$ & NS & $* *$ & $* *$ & $* *$ & $* *$ & $* *$ & $* *$ & $* *$ & $*$ \\
\hline \multicolumn{13}{|l|}{$\begin{array}{l}\text { Growing } \\
\text { condition }\end{array}$} \\
\hline Open field & 163.19 & 63.59 & 78.11 & 14.54 & 9.91 & 14.39 & 4.43 & 3.27 & 7.76 & 1.09 & 81.02 & 12.21 \\
\hline $\begin{array}{l}\text { Poly thene } \\
\text { covered }\end{array}$ & 109.99 & 55.36 & 66.67 & 11.91 & 7.59 & 12.05 & 3.63 & 2.86 & 6.58 & 0.99 & 75.77 & 10.19 \\
\hline Net covered & 135.38 & 58.76 & 71.40 & 13.21 & 10.91 & 17.33 & 5.56 & 3.79 & 9.39 & 1.42 & 86.93 & 13.17 \\
\hline LSD at $5 \%$ & 7.957 & 1.797 & 1.484 & 0.908 & 0.634 & 0.652 & 0.196 & 0.147 & 0.102 & 0.043 & 1.893 & 0.525 \\
\hline LSD at $1 \%$ & 10.76 & 2.429 & 2.006 & 1.227 & 0.857 & 0.881 & 0.265 & 0.199 & 0.137 & 0.059 & 2.560 & 0.709 \\
\hline $\begin{array}{l}\text { Level of } \\
\text { significance }\end{array}$ & $* *$ & $* *$ & $* *$ & $* *$ & $* *$ & $* *$ & $* *$ & $* *$ & $* *$ & $* *$ & $* *$ & $* *$ \\
\hline
\end{tabular}

\footnotetext{
$*$ Significance at $5 \%$ level, $* *=$ Significance at $1 \%$ level, NS $=$ Not Significant
} 
Table 2. Combined effect of variety and growing condition of stecklings on growth, yield contributing characters, yield and quality of carrot seed

\begin{tabular}{|c|c|c|c|c|c|c|c|c|c|c|c|c|}
\hline $\begin{array}{l}\text { Treatments } \\
\text { (Variety x } \\
\text { Growing } \\
\text { condition) }\end{array}$ & $\begin{array}{c}\text { Plant } \\
\text { height } \\
(\mathbf{c m})\end{array}$ & $\begin{array}{c}\text { Days to } \\
50 \% \\
\text { flowering }\end{array}$ & $\begin{array}{l}\text { Days } \\
\text { to } \\
50 \% \\
\text { fruit } \\
\text { set }\end{array}$ & $\begin{array}{c}\text { Days } \\
\text { required } \\
\text { for fruit } \\
\text { set }\end{array}$ & $\begin{array}{c}\text { Primary } \\
\text { umbels/ } \\
\text { plant }\end{array}$ & $\begin{array}{c}\text { Secondary } \\
\text { umbel/ } \\
\text { plant }\end{array}$ & $\begin{array}{l}\text { Yield of } \\
\text { primary } \\
\text { umbel } \\
\text { (g) }\end{array}$ & $\begin{array}{c}\text { Yield of } \\
\text { secondary } \\
\text { umbel }(\mathrm{g})\end{array}$ & $\begin{array}{c}\text { Seed } \\
\text { yield/ } \\
\text { plant } \\
(\mathrm{g})\end{array}$ & $\begin{array}{l}1000- \\
\text { seed } \\
\text { weight } \\
(\mathrm{g})\end{array}$ & $\begin{array}{c}\text { Germination } \\
\% \text { of seed }\end{array}$ & $\begin{array}{c}\text { Seed } \\
\text { vigour } \\
\text { index }\end{array}$ \\
\hline $\begin{array}{l}\text { Brasilia } \\
\text { Agroflora x } \\
\text { Open field }\end{array}$ & 174.75 & 61.89 & 76.53 & 14.20 & 10.28 & 15.66 & 4.72 & 3.38 & 8.14 & 1.17 & 83.51 & 12.58 \\
\hline $\begin{array}{l}\text { Brasilia } \\
\text { Agroflora x } \\
\text { Poly thene } \\
\text { covered }\end{array}$ & 114.65 & 54.23 & 65.34 & 11.34 & 8.53 & 12.80 & 3.81 & 3.02 & 6.91 & 1.01 & 77.33 & 10.63 \\
\hline $\begin{array}{l}\text { Brasilia } \\
\text { Agroflora x } \\
\text { Net covered }\end{array}$ & 146.64 & 57.45 & 69.70 & 12.51 & 11.24 & 18.60 & 5.83 & 3.95 & 9.91 & 1.55 & 88.76 & 13.44 \\
\hline $\begin{array}{l}\text { Prima } \\
\text { Agroflora } \mathrm{x} \\
\text { Open field }\end{array}$ & 163.67 & 63.67 & 77.62 & 14.32 & 10.02 & 14.14 & 4.42 & 3.25 & 7.71 & 1.11 & 80.66 & 12.31 \\
\hline $\begin{array}{l}\text { Prima } \\
\text { Agroflora x } \\
\text { Poly thene } \\
\text { covered }\end{array}$ & 109.54 & 55.25 & 66.43 & 11.82 & 7.66 & 12.13 & 3.63 & 2.84 & 6.61 & 0.99 & 75.55 & 10.31 \\
\hline $\begin{array}{l}\text { Prima } \\
\text { Agroflora x } \\
\text { Net covered }\end{array}$ & 133.22 & 58.49 & 71.35 & 13.36 & 11.21 & 17.19 & 5.62 & 3.83 & 9.45 & 1.40 & 87.10 & 13.06 \\
\hline $\begin{array}{l}\text { New } \\
\text { Kuroda x } \\
\text { Open field }\end{array}$ & 151.18 & 65.23 & 80.17 & 15.11 & 9.42 & 13.35 & 4.16 & 3.19 & 7.42 & 0.99 & 78.90 & 11.73 \\
\hline $\begin{array}{l}\text { New } \\
\text { Kuroda x } \\
\text { Poly thene } \\
\text { covered }\end{array}$ & 105.78 & 56.59 & 68.23 & 12.56 & 6.59 & 11.20 & 3.44 & 2.73 & 6.22 & 0.96 & 74.44 & 9.64 \\
\hline $\begin{array}{l}\text { New } \\
\text { Kuroda } x \\
\text { Net covered }\end{array}$ & 126.28 & 60.33 & 73.15 & 13.77 & 10.29 & 16.19 & 5.22 & 3.62 & 8.82 & 1.31 & 84.93 & 13.00 \\
\hline LSD at 5\% & 17.78 & 3.113 & 2.570 & 1.573 & 1.098 & 1.128 & 0.339 & 0.255 & 0.176 & 0.075 & 3.279 & 0.909 \\
\hline LSD at $1 \%$ & 18.63 & 4.208 & 3.474 & - & 1.484 & 1.525 & 0.459 & 0.344 & 0.238 & 0.102 & 4.433 & 1.228 \\
\hline $\begin{array}{l}\text { Level of } \\
\text { significance }\end{array}$ & $* *$ & $* *$ & $* *$ & $*$ & $* *$ & $* *$ & $* *$ & $* *$ & $* *$ & $* *$ & $* *$ & $* *$ \\
\hline
\end{tabular}

$*=$ Significance at $5 \%$ level, $* *=$ Significance at $1 \%$ level 

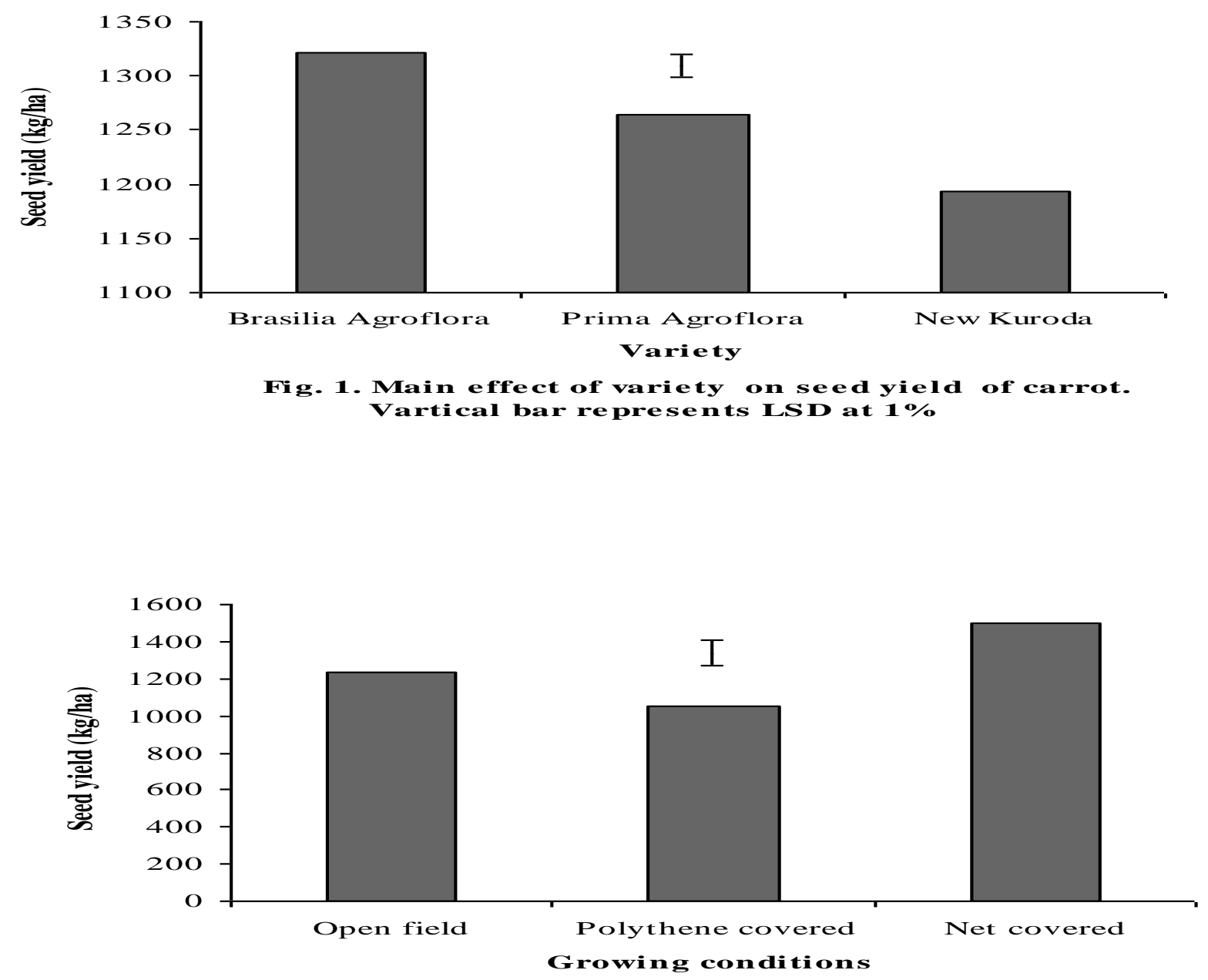

Fig. 2. Main effect of growing condition on seed yield of carrot. Vartical bar represents LSD at $1 \%$

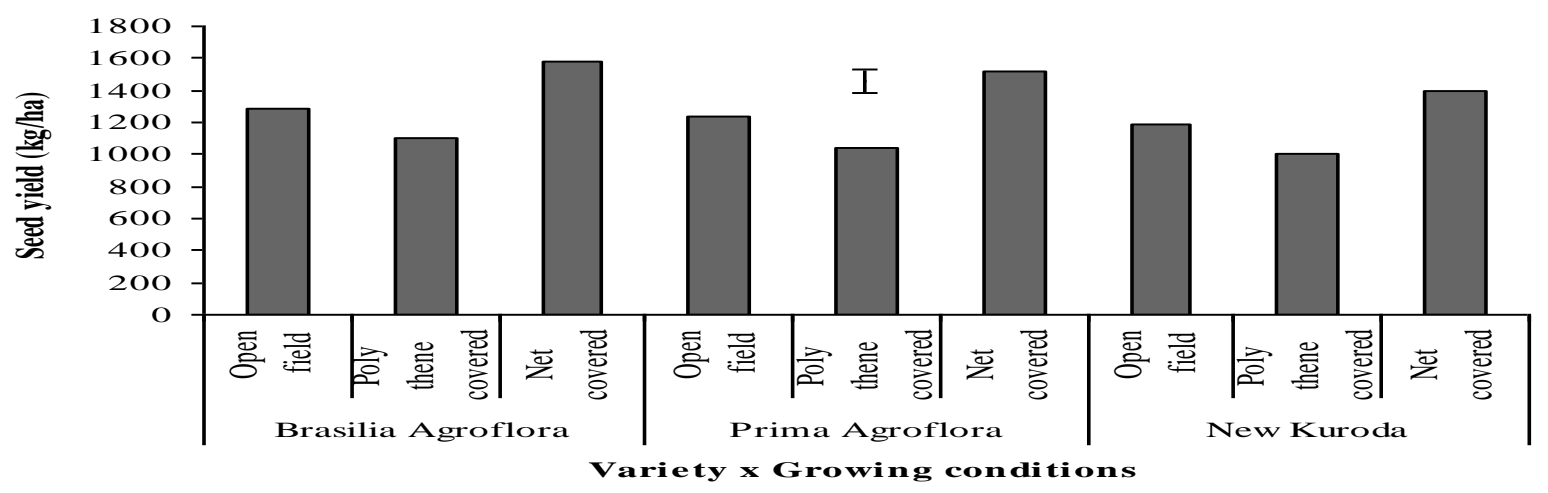

Fig. 3. Combined effect of variety and growing condition on seed yield of carrot. Vartical bar represents LS D at $1 \%$ 
Minimum days required for $50 \%$ flowering (55.36 days) was noted in polythene covered stecklings and open field took 63.59 days. Maximum days required (78.11 days) from $50 \%$ flower to fruit set was found in open field conditions stecklings and minimum time (66.67 days) from polythene covered stecklings. The highest number of primary umbels/plant (10.91) was recorded in net covered stecklings, while the lowest (7.59) in polythene covered stecklings. The highest seed yield in primary umbel (10.91g) was observed in net covered stecklings followed by open field stecklings $(9.91 \mathrm{~g})$, while polythene covered stecklings demonstrated the lowest $(7.59 \mathrm{~g})$.

The net covered steckling gave the highest seed yield/ha $(1495.33 \mathrm{~kg})$ followed by open field stecklings $(1236.27 \mathrm{~kg})$ whereas, it was the lowest $(1047.14 \mathrm{~kg})$ in polythene covered (Fig. 2). This might be due to under net covered stecklings was helpful for vegetative growth, flowering, fruit setting and thus, the seed production of carrot increased. The highest 1000 -seed weight $(1.42 \mathrm{~g})$ was recorded in net covered stecklings, while polythene covered occurred the lowest $(0.99 \mathrm{~g})$. The highest quality of seed (germination $86.93 \%$ and vigour index 13.17) was exhibited in net covered stecklings and polythene covered stecklings gave the lowest $(75.77 \%$ \& 10.19).

\section{Combined effect of variety and growing condition}

Highly significant variations were observed of all the parameters under study due to combined effects of variety and growing condition of stecklings (Table 2). The tallest plant height $(174.75 \mathrm{~cm})$ was recorded in treatment combination of Brasilia Agroflora with open field condition stecklings treatment, while the most dwarf $(105.78 \mathrm{~cm})$ in New Kuroda with polythene covered. The longest days to $50 \%$ flowering (65.23 days) were required in the combination of New Kuroda with open field condition stecklings, while the shortest period (54.23 days) from Brasilia Agroflora with polythene covered. The highest time required (15.11 days) from flower to fruit set was found in New Kuroda with open field stecklings and the lowest time (11.34 days) in the variety of Brasilia Agroflora with polythene covered stecklings. The highest number of primary umbels/plant (11.24) was recorded in Brasilia Agroflora with net covered stecklings, while the lowest (6.59) in Brasilia Agroflora with polythene covered.
Maximum seed yield in primary umbel $(5.83 \mathrm{~g}$ ) was observed in Brasilia Agroflora with net covered stecklings, while New Kuroda with polythene covered demonstrated the lowest seed yield (3.44g). Brasilia Agroflora with net covered stecklings obtained the highest seed yield/ha $(1576.07 \mathrm{~kg})$ and it was the lowest $(1000.10 \mathrm{~kg})$ in New Kuroda with polythene covered (Fig. 3). Maximum 1000-seed weight (1.55g) was recorded in Brasilia Agroflora with net covered stecklings, while the New Kuroda with polythene covered stecklings gave minimum weight $(0.96 \mathrm{~g})$. The highest quality of seed (germination $88.76 \%$ and vigour index 13.44) was exhibited in Brasilia Agroflora with net covered stecklings, while the lowest $(74.44 \%$ \& 9.64) was observed under New Kuroda with polythene covered stecklings.

\section{References}

Agrawal, R. L. 1996. Seed Technology. $2^{\text {nd }}$ edn. Oxford and IBH Pub. Co. pvt. Ltd., 66 Janpath, New Delhi. p. 829.

Cardoso, A.I. 2000. Yield and quality of carrot seeds from cultivars Brasilia and Carandai. Bragantia, 59(1): 77-81.

Malik, Y. S.; Singh, K. P. and Yadav, P. S. 1983. Effect of spacing and number of umbels on yield and quality of seed in carrot (Daucus carota L.). Seed Res., 11(1): 63-67.

Mohanty, B.K. 1998. Some experience with growing carrot seed. J. Maharashtra Agril. Univ., 25(3): 271-273.

Mohanty, B.K. and Prusti, A.M. 2001. Studies on genetic for production of seed crops. Research on crops. 2(3): 378-381.

Shantha, N., Pandita, V.K. and Deepti, S. 1998. Effect of sowing time and umbel order on emergence characteristics of Asiatic carrot Daucus carota L. Seed Res., 26(2): 125-130.

Sharma, S.K.; Gulshan, L. and Lal, G. 1990. Effect of nitrogen fertilizer, plant spacing and steckling size on certain morphological characters and seed yield in radish. Veg. Sci., 18(1): 82-87. 